\title{
EFFECTS OF LIVE VIDEO STREAMING TOWARDS ONLINE PURCHASE INTENTION
}

\author{
Lim Kah Boon ${ }^{1, *}$, Yeo Sook Fern ${ }^{1}$, and Alfredo Hiew Kya Way ${ }^{1}$ \\ ${ }^{1}$ Faculty of Business, Multimedia University, 75450 Melaka, Malaysia.
}

\begin{abstract}
Online video streaming is one of the channels of the current economic development of e-commerce. In this technology era, our lifestyle is gradually moving towards electronic development and the public use of e-commerce applications for their businesses. Online video streaming strategies, therefore, benefit marketers, and this is mainly due to their cost-effective properties. The main objective of this research is to investigate the influences of online video streaming on customers' online purchase intention. Three independent variables include perceived credibility, perceived ease of use and perceived usefulness are used to study the influence of online video streaming on the consumers' online purchase intention. A set of self-administered questionnaires was distributed to 215 respondents from three states in Malaysia which are Johor, Melaka and Selangor, who had the experience of online purchases that were affected by online video streaming. The collected data are then analysed using SPSS and Smart PLS software. The results of the analysis indicated that all three independent variables have a significant impact on consumers' online purchase intentions through online video streaming. In conclusion, this research is important to e-marketers in order to allow them to gain a better understanding of the online purchasing behaviour of their customers.
\end{abstract}

\author{
ARTICLE HISTORY \\ Received: 1-3-2021 \\ Revised: 7-4-2021 \\ Accepted: 17-5-2021 \\ KEYWORDS \\ Attitude \\ live video streaming \\ purchase intention \\ perceived credibility \\ perceived ease of use
}

\section{INTRODUCTION}

E-business has grown rapidly online in these few decades. In this new era, e-retailers embraced new digital marketing strategies that will give their customers more authentic information. E- retailers use online video streaming or so called live video streaming to show the details of the information of their products. Online video streaming is one of the channels of e-commerce economic development in a country. If certain consumers feel interested of their product, e-marketers will respond back immediately from the online video streaming to the question those customers had asked. Online video streaming also allows customers to get more clearly product information. Every marketer has wished to capture their customers' attention and know their intention to purchase through online. The rise of the popularity of online video streaming has also attracted the attention from many researchers. They focused on measuring the subjective qualities of the online video streaming (Wamser, 2017).

In China, the Internet Network Information Centre reported that by the end of 2017, 422 million people had used online video streaming users. These data showed an increase of $22.7 \%$ over 2016. There are multiple social media platforms that build online video streaming platforms like Facebook Live, YouTube, Twitter and more. Starting in 2015, e-retailers are starting to use online video streaming to find a new way to engage consumers and keep their products competitive. The behavioural intentions of various customers may be affected by different types of online video streams (such as video games, sales and promotions, and music) (Hu, Zhang \& Wang, 2017). These days of online video streaming are used on e-commerce sites to provide product information, experience and interaction with potential clients. Some researchers suggest that customers will experience less perceived uncertainty and psychological distance through prepurchasing product information online (Fiedler, 2007). This is because online video streaming offers customers the opportunity to interact with e-retailers in real time and gain more credible and specific online product information. Online video streaming is a very useful way for e-retailers to promote their products in a very useful and cost-effective way to promote their products. Video is an effective way to show customers the uniqueness of their products (Chen, Yeh \& Chang, 2020). In addition, online video streams can provide visual, motion and sound effects when delivering product information to consumers (Yen, 2018). Online video streaming is therefore a very reliable way for consumers to obtain the product information they want.

Hence, the main objective of this study is to analyse the influences of live video streaming towards customers' online purchase intention. There are total of three independent variables which are perceived credibility, perceived usefulness and perceived ease of use are studied in this research. The remainder paper is followed by the discussion of literature review, methodology which applied in this study. Then, the discussion is continued with the findings of this study and lastly is the conclusion to summarise this study. 


\section{LITERATURE REVIEW}

Purchase intention is the last stage that comes to the customers' mind. Purchase intention also can be defined as an action of customers to purchase something that they want. It is representing on what the customers analyse, evaluate, thinks and will purchase it when they find out that the product and services is worth buying or not (Blackwell, Miniard, \& Engel, 2001). In addition, marketers can use purchase intention to predict future customers demand for their products. (Armstrong, Morwitz, \& Kumar, 2000). This research focuses on purchasing decisions rather than behaviour due to purchases always have a relationship to the individual's behaviour and have a wider implication (Ajzen \& Driver, 1992).

Next, the discussion is focused on the definition of each independent variable. First, perceived credibility is a concept that is defined by the reader's judgment (Freeman, 2004). Literature studies have shown that perceived credibility depends not only on the source, message characteristics or platform, but also on the recipient's perception (Johnson, 2008). Perceived credibility is the dimension of trust that influences the adoption of information in a positive or negative way and can lead to changes in consumer attitudes (Bouhlel, 2010). The credibility of the source is very important to consumers these days. This is because many people are being cheated by the online commerce. This is because the consumers did not understand the background of a particular seller and frequent ignorance of the customers towards the Feedback and the rating of the particular product. And this will lead to the customers being cheated. Rating is important for assessing the credibility of online content (Flanagin et al.,2011). Furthermore, the number of likes and comments are also very important to determine whether the source is credible or not. For instance, when there many people that likes and comments to a certain online video streaming. The customers will feel that the product that they are offering online are very useful to the peoples and with all the good comments that others people made. You will probably feel that it is very reliable and credible to trust on the product. More credible sources have succeeded in establishing a more positive attitude (Chu and Kamal, 2008). Mir and Zaheer (1970) demonstrated that the perceived credibility has a positive impact on purchase intention.

H1: There is a significant relationship between perceived credibility and consumers' online purchase intention through online video streaming.

Next, perceived usefulness can be said as a person's believes where the use of a system is able to enhance the job performance of a people (Davis, 1989). Perceived usefulness also related to a person's expectations of a good outcome at the end (McKnight, 2007). Besides that, peoples in these days want convenience and they are more likely to try something that can meet their needs in a very useful way. Pavlou and Fygenson (2006) defined the usefulness of the website information as the validity of such information to enhance access to product information. Next, according to the Technology Acceptance Model (TAM), perceived usefulness will affect the attitudes towards purchasing a product (Shareef et al., 2013). By entering the video streaming session, you will be able to use the system and it will be convenience to the user. Hsu et al. (2013) found that the usefulness of blog, website and streaming recommendations will effect in the attitudes. It will also show an indirect effect on the customer purchase intention. Perceived usefulness is very important to the customers purchase intention. It is the process of a customer decision whether the customers are willing to buy to a certain product and the information that get are relevant to their wants. Furthermore, customers will get more detail product information through online video streaming because the host which is the seller will provide many useful information of the product will convenience then and lead to purchase (Kim \& Song, 2010). Otherwise, online shoppers will turn to competitors because many other online stores have similar products on sale (Kim \& Song, 2010).

H2: There is a significant relationship between perceived usefulness and consumers' online purchase intention through online video streaming.

Lastly, Sulistiyaningsih (2014) defined perceived ease of use as the degree to which customers see development of something ease of use. This means that perceived ease of use is something that you feel that the systems, the website or an online platform is easy to use and convenience to the customers. Online video streaming platform is something easy for the customers to use. Different types of online video streaming (e.g. videogames, selling and promoting and music) will influences different customers' behavioural intention (Ma et al., 2017). Customers can directly go to Facebook Live and see the streaming of a particular product that is promoted by a host. Customers just need to place a comment, and the host will reply whatever question that customers are asking ( $\operatorname{Lin} \& \mathrm{Lu}, 2000)$. Announces that ease of use is determined that whether the data is openness and innovation enough. This is because customers love something that is new and at the same time easy to use. And so, online video streaming has help customers in this aspect. To illustrate, customers no need to go for other website to do research of a particular product and customers no need to waste their time to go to a shopping mall to look for their product. All information is already providing on the live video streaming, just a click in to the live streaming and customers will be able to buy know about product description and if they have any question, they can ask on the comment session (Davis, 1989). The extent to which the individual believes in use a specific information technology system will be effortless. Thus, perceived ease of use will influence on the customers' online purchase intention.

H3: There is a significant relationship between perceived ease of use and consumers' online purchase intention through online video streaming. 


\section{METHODOLOGY}

The convenience sampling method is applied in this study. Based on the calculation of $\mathrm{G}^{*}$ power, the minimum required sample size is 129 respondents. A set of self-administered questionnaire has been distributed to 250 respondents in three states of Malaysia which are Johor, Melaka and Selangor. The complete 215 sets of survey questionnaires were used for data analysis in this study. The set of questionnaire is divided into three main sections which cover demographic variables, the measurement items for independent and dependent variables. The measurement items for the independent variables are adopted from Yüksel (2016) and Zhu et al. (2006) while the measurement items for dependent variable are adopted from Hsu and Tsou (2011). A five-point Likert scale ( $1=$ strongly disagree to $5=$ strongly agree $)$ is applied in this study. Data are keyed into SPSS version 25 and followed by using Partial Least Square Structural Equation Modelling (PLS-SEM 3.2.7) to assess the hypothesis.

\section{FINDINGS AND DISCUSSION}

The discussion of our result is first focused on the demographic features of the respondents such as the respondents' gender age, monthly income and occupation. The demographic profile of the respondents is summarised in Table 1 . The respondents that took part in this study are mostly male, which is $60.9 \%$ and followed by $39.1 \%$ of the respondents are female respondents. The 18-20 years old age group have 41 respondents (19.1\%) out of the 215 respondents. The age group of 21-23 years old age group possessed the highest number of respondents which is 70 respondents (32.6\%) whiles the lowest respondents that participated in this research are the 30 above age range which have only 32 respondents (14.9\%). Next, is the number in the $24-26$ years old age group have 34 respondents (15.8\%) that participated in this research which is lower than the 27-29 age group that possessed 38 respondents $(17.7 \%)$. There are a great number of respondents which is the $50.7 \%$ or equivalent to 109 respondents where their monthly income levels are below RM2,000. Next, $21.4 \%$ or 46 respondents are in the range of RM3,000-RM3,999. Then, followed by $16.3 \%$ of the respondents possesses for 35 numbers of respondents in the range of RM2,000-RM2,999. Next, 11.6\% or 25 respondents are in the category of RM4,000 and above. For the occupation category of the respondents, the largest number are students which are accounted by $48.4 \%$ and 104 respondents. Furthermore, self-employed contributed the less in this survey with only the amount of 2 respondents $(0.9 \%)$. Besides that, there are also a large amount of peoples that are in the area of private sector which is 87 respondents $(40.5 \%)$. However, government servant contributed the least with only 1 respondent $(0.5 \%)$. Last but not least, $9.8 \%$ of the respondents possesses for 21 respondents are categorised in the others category.

Table 1. Summary of respondents' profile

\begin{tabular}{|c|c|c|}
\hline Demographic profile & Frequency & Percentage $(\%)$ \\
\hline \multicolumn{3}{|l|}{ Gender } \\
\hline Male & 131 & 60.9 \\
\hline Female & 84 & 39.1 \\
\hline \multicolumn{3}{|l|}{ Age } \\
\hline $18-20$ years old & 41 & 19.1 \\
\hline $21-23$ years old & 70 & 32.6 \\
\hline $24-26$ years old & 34 & 15.8 \\
\hline $27-29$ years old & 38 & 17.7 \\
\hline Above 30 years old & 32 & 14.9 \\
\hline \multicolumn{3}{|l|}{ Monthly Income } \\
\hline Less than RM2000 & 109 & 50.7 \\
\hline RM2000 - RM2999 & 35 & 16.3 \\
\hline RM3000 - RM3999 & 46 & 21.4 \\
\hline RM4000 and above & 25 & 11.6 \\
\hline \multicolumn{3}{|l|}{ Occupation } \\
\hline Government Servant & 1 & 0.5 \\
\hline Private sector & 87 & 40.5 \\
\hline Self-employed & 2 & 0.9 \\
\hline Student & 104 & 48.4 \\
\hline Others & 21 & 9.8 \\
\hline
\end{tabular}

Next, the convergent validity measures result of all the measurement items are summarise in Table 2. The reliability tests and construct validity had to achieve an acceptable range before the Structural Equation Modelling is applying. Our results show that all the items loadings are range from 0.551 to 0.859 and this indicates that all the item loadings are meeting the minimum requirement (Chin, 1998). Furthermore, the composite validity (CR), Rho_A and average variance extracted (AVE) values for all the four variables were above 0.7 and 0.5 respectively. According to Hair et al. (2016), a strong valid model covered factor loading above 0.5, AVE values above 0.5, CR and Rho_A values above 0.7. Hence, our analysis results confirmed that the model constructs fulfilled the convergent validity and internal 
consistency. Furthermore, Table 3 illustrates all the values of Heterotrait-Monotrait (HTMT) criteria were lower than the required threshold value of HTMT 0.90 by Gold, Malhotra and Segars (2001). Hence, the discriminant validity was verified and proved, and this indicates that the proposed hypotheses were accepted.

Table 2. Convergent validity assessment

\begin{tabular}{|c|c|c|c|c|c|c|}
\hline $\begin{array}{r}\text { Model } \\
\text { construct }\end{array}$ & Items & Loadings & AVE & CR & CA & Rho_A \\
\hline & OPI1 & 0.683 & 0.610 & 0.886 & 0.839 & 0.848 \\
\hline Online & OPI2 & 0.804 & & & & \\
\hline Purchase & OPI3 & 0.859 & & & & \\
\hline \multirow[t]{2}{*}{ Intention } & OPI4 & 0.717 & & & & \\
\hline & OPI5 & 0.830 & & & & \\
\hline \multirow{4}{*}{$\begin{array}{l}\text { Perceived } \\
\text { Credibility }\end{array}$} & PC1 & 0.551 & 0.507 & 0.802 & 0.683 & 0.718 \\
\hline & PC2 & 0.775 & & & & \\
\hline & PC3 & 0.706 & & & & \\
\hline & PC4 & 0.790 & & & & \\
\hline \multirow{4}{*}{$\begin{array}{l}\text { Perceived } \\
\text { Ease of Use }\end{array}$} & PEOU1 & 0.698 & 0.549 & 0.829 & 0.729 & 0.749 \\
\hline & PEOU2 & 0.712 & & & & \\
\hline & PEOU3 & 0.735 & & & & \\
\hline & PEOU4 & 0.814 & & & & \\
\hline \multirow{3}{*}{$\begin{array}{l}\text { Perceived } \\
\text { Usefulness }\end{array}$} & PU1 & 0.834 & 0.584 & 0.806 & 0.660 & 0.706 \\
\hline & PU3 & 0.792 & & & & \\
\hline & PU5 & 0.655 & & & & \\
\hline
\end{tabular}

Table 3. Heterotrait-Monotrait Ratio (HTMT) for discriminant validity

\begin{tabular}{ccccc}
\hline & $\begin{array}{c}\text { Online } \\
\text { Purchase Intention }\end{array}$ & $\begin{array}{c}\text { Perceived } \\
\text { Credibility }\end{array}$ & $\begin{array}{c}\text { Perceived Ease } \\
\text { of Use }\end{array}$ & $\begin{array}{c}\text { Perceived } \\
\text { Usefulness }\end{array}$ \\
\hline $\begin{array}{c}\text { Online } \\
\text { Purchase Intention }\end{array}$ & 0.813 & & & \\
\hline $\begin{array}{c}\text { Perceived } \\
\text { Credibility }\end{array}$ & 0.755 & 0.720 & & \\
\hline $\begin{array}{c}\text { Perceived Ease } \\
\text { of Use }\end{array}$ & 0.822 & 0.849 & 0.687 \\
\hline $\begin{array}{c}\text { Perceived } \\
\text { Usefulness }\end{array}$ & & & \\
\hline
\end{tabular}

Hair et al. (2016) mentioned that statistical significance can be accessed through the application of the bootstrapping technique. In this study, the minimum number of bootstrap samples is 5000 times. Figure 1 illustrates the values of $\mathrm{R}^{2}$ and the structural model of this study. The $\mathrm{R}^{2}$ value of the model is 0.596 which means that $59.6 \%$ of the variation in online purchase intention can be explained by the three independent variables which are perceived credibility, perceived ease of use and perceived usefulness. 


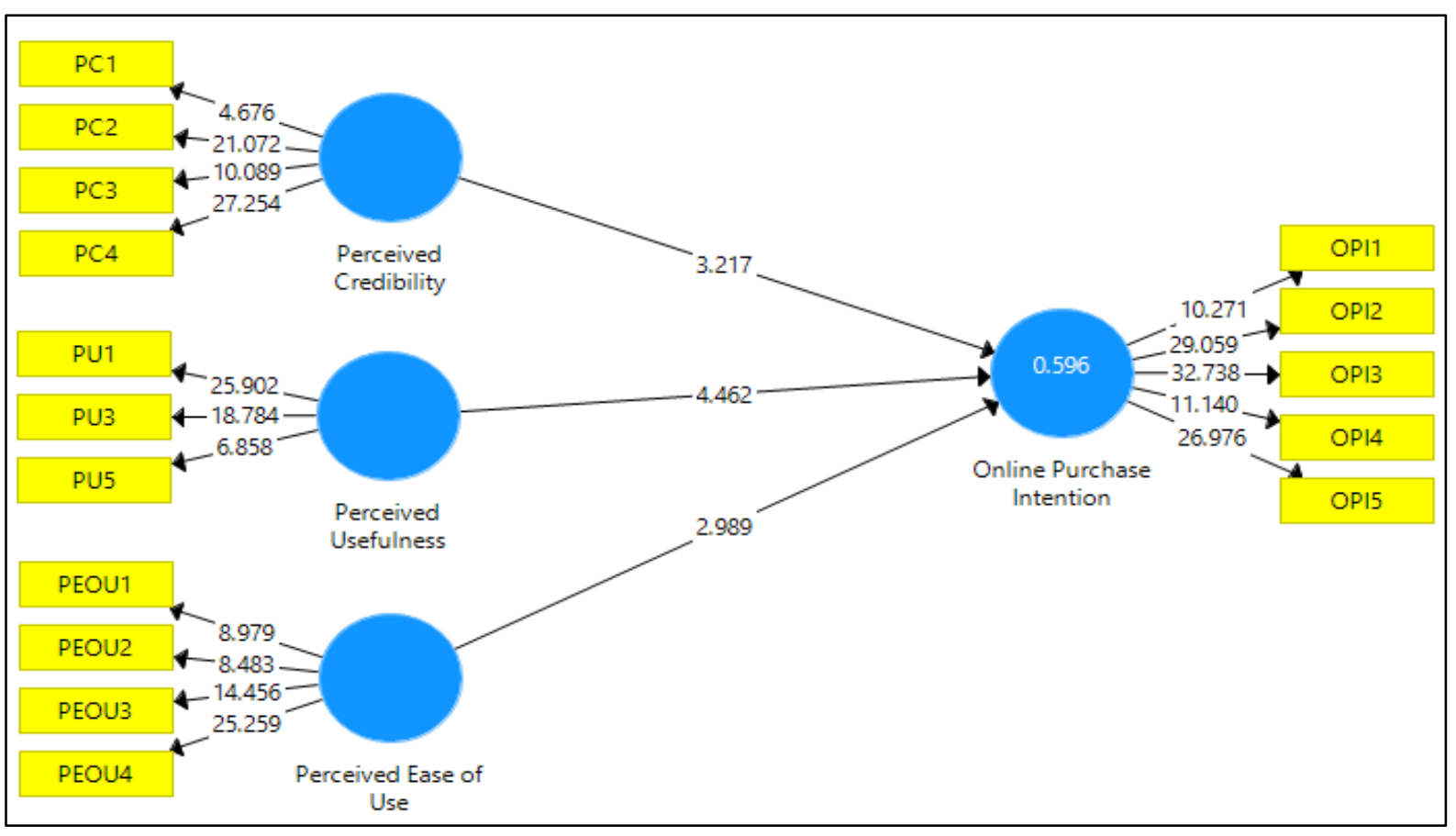

Figure 1. Structural model

The summary of the hypothesis testing result is shown in Table 4 . The hypothesis result indicates that all the three hypotheses were supported at a minimum of $1 \%$ significance level.

Table 4. Result of the hypothesis testing

\begin{tabular}{|c|c|c|c|c|c|c|}
\hline Relationship & $\begin{array}{c}\text { Std } \\
\text { Beta }\end{array}$ & $\begin{array}{l}\text { Std } \\
\text { Error }\end{array}$ & t-value & LL & UL & Decision \\
\hline $\begin{array}{c}\text { Perceived } \\
\text { Credibility } \rightarrow \text { Online } \\
\text { Purchase Intention }\end{array}$ & 0.278 & 0.087 & $3.217 * *$ & 0.146 & 0.430 & Supported \\
\hline $\begin{array}{c}\text { Perceived Ease of } \\
\text { Use } \rightarrow>\text { Online } \\
\text { Purchase Intention }\end{array}$ & 0.294 & 0.098 & $2.989 * *$ & 0.136 & 0.453 & Supported \\
\hline $\begin{array}{c}\text { Perceived } \\
\text { Usefulness } \rightarrow \text { Online } \\
\text { Purchase Intention }\end{array}$ & 0.360 & 0.081 & $4.462 * *$ & 0.235 & 0.497 & Supported \\
\hline
\end{tabular}

Firstly, this research found out that the perceived credibility is an important key for the consumer's online purchase. This is because there is a significant relationship with perceived credibility and the online purchase intention. Marketers must make sure that they are delivering the true product information and must be always credible for the customers. Thus, by continuing doing this, the marketers will have a very good response and ratings for their online tools and reviews. Hence, by continuous improving and providing credible source, the marketers will be much benefited as the perceived already have significant relationship with the online purchase intention.

Next, is the perceived usefulness such a how good that the information that the customers receive. The important is whether that the customers feel useful or not about the information provided on the online video streaming. Since, there is significant relationship between this perceived usefulness and the online purchase intention. So the marketers must think about how to attract the customers, especially the youngster because there is a lot of source and platform out there that can obtain particular product information very easily. So this will lead to the customers to feel that there is not so useful to obtain and know about product information from the online video streaming. Thus marketers should improve in this aspect, for examples by using influencer to persuade the customers and the influencer are also using the product, so this will attract the customers and will make them feel that the information that they get are useful for them.

Furthermore, this study helps the marketers to know about the important about the perceived ease of use to the customers and at the end lead to the online purchase intention since there is a significant relationship with the variables and the dependent variables. Marketers should keep on make the online video streaming tools easy to use, for examples make the supporting tools to be attractive and not complicated for the customers to use it. This will ensure that the customers feel very satisfying using the tools and will help to increase the ease of use of the supporting tools. 


\section{CONCLUSION}

This research is to establish that the online video streaming impacts against consumer's intention to buy online. This study also presents the correlation between the variables and the consumer's intention to buy online and it can also benefit other researchers to use this study as one of their references for their study. Besides that, this research can benefit to the marketers and this will let the marketers to know more about what the customers really want and the most important is the marketers can know about which variable will impact the customer's attitudes and then lead them to the online purchase intention. Therefore, marketers will know about which variables to use then from this they can convince the customers to buy their product and so this can increase the sales for the marketers.

Our analysis result showed that all three independent variables have significant relationship towards consumers' online purchase intention through live video streaming. The findings of this research showed that perceived credibility is an important key for the consumer's online purchase. Marketers must make sure that they are delivering the true product's information and must be always credible for the customers. Thus, by continuing doing this, the marketers will have a very good response and ratings for their online tools and reviews. Furthermore, this study helps the marketers to know about the important about the perceived ease of use to the customers. Marketers should maintain the online video streaming tools as easy to use. This will ensure that the customers feel very satisfying using the tools and will help to increase the ease of use of the supporting tools.

In conclusion, this research is important to the e-marketers in order to let them to have a better understanding of the customers' online purchase behaviour. This research is to establish that the online video streaming impacts against consumer's intention to purchase online. Besides that, this research can benefit to the marketers as this will let the marketers know more about what the customers really want and which variable will impact the customer's attitudes and then lead them to the online purchase intention.

\section{REFERENCES}

Ajzen, I., \& Driver, B. L. (1992). Contingent value measurement: On the nature and meaning of willingness to pay. Journal of Consumer Psychology, 1(4), 297-316.

Armstrong, J. S., Morwitz, V. G., \& Kumar, V. (2000). Sales forecasts for existing consumer products and services: Do purchase intentions contribute to accuracy?. International Journal of Forecasting, 16(3), 383-397.

Blackwell, R. D., Miniard, P. W., \& Engel, J. F. (2001). Consumer behavior 9th. South-Western Thomas Learning. Mason, $\mathrm{OH}$.

Bouhlel, O. M. (2010). Online Purchase Intention, Understanding the Blogosphere Effect. , 37-51.

Chen, T. Y., Yeh, T. L., \& Chang, C. I. (2020). How different advertising formats and calls to action on videos affect advertising recognition and consequent behaviours. The Service Industries Journal, 40(5-6), 358-379.

Chin, W. W. (1998). The partial least squares approach to structural equation modelling. Modern methods for business research, 295(2), 295-336.

Chu, S. C., \& Kamal, S. (2008). The effect of perceived blogger credibility and argument quality on message elaboration and brand attitudes: An exploratory study. Journal of interactive Advertising, 8(2), 26-37.

Davis, F. D. (1989). Perceived usefulness, perceived ease of use, and user acceptance of information technology. MIS quarterly, 319-340.

Flanagin, A. J., \& Metzger, M. J. (2011). From Encyclopaedia Britannica to Wikipedia: Generational differences in the perceived credibility of online encyclopedia information. Information, Communication \& Society, 14(3), $355-374$.

Fiedler, K. (2007). Information ecology and the explanation of social cognition and behavior.

Freeman, K. S. (2004). An Examination of Factors that Affect the Credibility of Online Health Information. Technical Communication, 239-263.

Gold, A. H., Malhotra, A., \& Segars, A. H. (2001). Knowledge management: An organizational capabilities perspective. Journal of Management Information Systems, 18(1), 185-214.

Hair Jr, J. F., Hult, G. T. M., Ringle, C., \& Sarstedt, M. (2016). A primer on partial least squares structural equation modeling (PLS-SEM). Sage publications.

Hsu, C. L., Lin, J. C. C., \& Chiang, H. S. (2013). The effects of blogger recommendations on customers' online shopping intentions. Internet Research.

Hsu, H. Y., \& Tsou, H. T. (2011). Understanding customer experiences in online blog environments. International Journal of Information Management, 31(6), 510-523.

$\mathrm{Hu}$, M., Zhang, M., \& Wang, Y. (2017). Why do audiences choose to keep watching on live video streaming platforms? An explanation of dual identification framework. Computers in Human Behavior, 75, 594-606.

Johnson, T. J. (2008). Every Blog Has Its Day: Politically-Interested Internet Users' Perceptions of Blog Credibility. Journal of Computer Mediated Communication, 100-122.

Kim, H., \& Song, J. (2010). The quality of word-of-mouth in the online shopping mall. Journal of Research in Interactive Marketing.

Lin, J. C. C., \& Lu, H. (2000). Towards an understanding of the behavioural intention to use a web site. International Journal of Information Management, 20(3), 197-208.

Ma, Y. J., Gam, H. J., \& Banning, J. (2017). Perceived ease of use and usefulness of sustainability labels on apparel products: application of the technology acceptance model. Fashion and Textiles, 4(1), 3.

McKnight, D. H. (2007). Factors and Effects of Information Credibility. Proceedings of the Ninth International 
Conference on Electronic Commerce, 423-432.

Mir, I., \& Zaheer, A. (1970). Verification of social impact theory claims in social media context. The Journal of Internet Banking and Commerce, 17(1), 1-15.

Pavlou, P. A., \& Fygenson, M. (2006). Understanding and predicting electronic commerce adoption: An extension of the theory of planned behavior. MIS quarterly, 115-143.

Shareef, M. A., Archer, N., Fong, W., Rahman, M. O., \& Mann, I. J. (2013). Online buying behavior and perceived trustworthiness. Current Journal of Applied Science and Technology, 662-683.

Sulistiyaningsih. M., T. J. (2014). Technology Acceptance Model and Online Learning Media: An Empirical Study of Online Learning Application In a Provate Indonesian University. Journal of Theoretical and Applied Information Technology, 136-144.

Wamser, F. L.-G. (2017). Dynamic cloud service placement for live video streaming with a remote-controlled drone 2017 IFIP/IEEE symposium on .

Yen, Y. S. (2018). Route factors influencing trust and attitude toward TV shopping. The Service Industries Journal, 38(78), 402-430.

Yüksel, H. F. (2016). Factors affecting purchase intention in YouTube videos. The Journal of Knowledge Economy \& Knowledge Management, 11(2), 33-47.

Zhu, L., Benbasat, I., \& Jiang, Z. (2006). Investigating the role of presence in collaborative online shopping. AMCIS 2006 Proceedings, 358.

\section{AUTHORS' BIOGRAPHY}

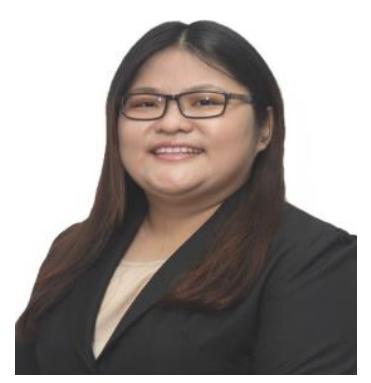

Dr. Lim Kah Boon is a lecturer in the Faculty of Business at the Multimedia University. She graduated with Doctor of Philosophy (Ph.D.) degree majoring in Econometrics from the Universiti Sains Malaysia. Her current research interests include econometric, mathematical modelling, applied mathematics and statistical analysis.

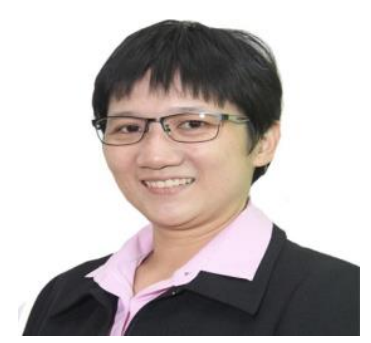

Dr Yeo Sook Fern is a Lecturer at the Faculty of Business, Multimedia University, Melaka. She commenced her career as a lecturer, with 18 years of teaching experience. She teaches marketing for bachelor degree programmes, specifically Understanding Management, Fundamentals of Marketing, Service Marketing, Brand Management and Strategic Marketing.

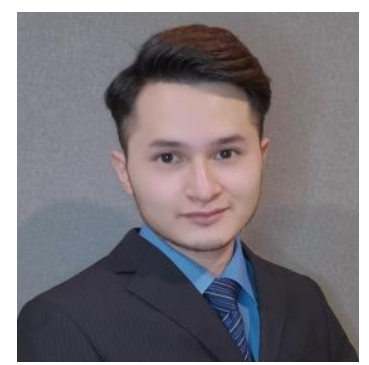

Mr. Alfredo Hiew Kya Way is a graduate of Bachelor of Business Administration (Hons.) Marketing Management from Multimedia University, Melaka. 